\title{
Reconceptualising urban development in exceptional territories: Nicosia
}

\author{
R. A. Atun \\ Faculty of Architecture, Eastern Mediterranean University, North Cyprus
}

\begin{abstract}
Urban territories have experienced certain transformations throughout different time-spans defined by certain benchmarks, depending on global (context free) and local (context dependent) parameters. Each territory has certain exceptional features according to its contextual characteristics; however, there are some territories which have certain 'exceptionalities' that become part of its very essence such as Nicosia, the divided capital of Cyprus. The disturbances, based on ethnicity, shaped the urban structures, affecting the overall process of urban development. In this paper, the development of city structure will be evaluated upon process of 'urban transformation' including historical evolution of city structure, the experienced urban disturbances resulting from division, and a future urban integration as an essential step towards sustainable urban development. Also, the exceptionality, altering in each step of urban transformation of the city, will be considered as an attribution of different dynamics related with ethnic, socio-political and environmental aspects of developments. Urban transformation is going to be reconceptualised into three parts with a retrospective approach. The first part of the article is focused on exploring the formation of city structure that is evolved throughout history upon utility-based developments. The second part focuses on assessing the deformation of city structure upon ethnic conflict between Turkish and Greek Cypriots, dominated by 'power struggle'. The final part analyzes the reformation of city structure, attempted upon EU process where sustainable urban development is the goal. The substantial resources that has allocated in restructuring Nicosia will be questioned, where urban regeneration is accepted as a tool in re-structuring the city with exceptionality.

Keywords: exceptional territories, sustainable urban development, urban division, urban integration, urban regeneration.
\end{abstract}




\section{Introduction}

While the purpose of this paper does not permit a detailed exploration of wider social science debates on 'space' and 'place' it does necessitate a brief discussion of the relationship between these two concepts.

Low [1] defines city as '...not reification but the focus of cultural and sociopolitical manifestation of urban lives and everyday practices'. The city is a mirror-image of the social configuration of the society, where societal network can be observed clearly. Bourdieu [2] describes social space, as a place where individuals and groups position and he demonstrates how social divisions within/in between groups are projected on space-time organization. Penetration of power in the socio-spatial system of relations also becomes important, where power accepted as an inevitable mechanism reproduced space according to different dynamics resulting with changing socio-spatial representations and practices. Therefore, the social production/re-production of space can be accepted as the outcome of changing mechanisms in which aims to control, to dominate and wield power (see Bourdieu [2], Low [3], Merrifield [4,5], Lefebvre [6]).

The mutual and dynamic relation between the given statements requires dialectical argumentation that the socio-spatial and political representations can be explored by addressing the question of 'change'. As Ollman [7] insists, 'given that change is always a part of what things are, the problem for research can only then be how, when and what they change and why they sometimes appear not to change'. Therefore the change is accepted as the very essence of the city.

In order to be able to perceive the change, dialectics emphasize process, movement, flow, relations and, more particularly, contradiction (Ollman [7]; Murray [8]), see also Harvey [9]. Therefore, a process of development has to be considered along a spatial and social continuum; where space is produced, transformed and used through different patterns of practices regarding the diversified forms of change.

In Nicosia, process is composed of certain stages of development, generating various degrees of contextual differentiations. It is argued that the existing reformation process will provide a context which is favourable to the emergence of sustainable urban regeneration in terms of policies and projects which will contribute to the city's economic development; improve the quality of life of Nicosia citizens and protect and enhance the built environment (Kocabaş and Gibson [10]). As regeneration strategies are accepted a vehicle for triggering the existing potential of the city, the question of whether urban regeneration has the potential to restructure the division in city will be considered accordingly. In order to be able to define the tools and mechanisms for the re-structuring of city, understanding the mutual relation among different layers of development is essential to support any timely and sustainable transition from a partially to a completely integrated city. The strategic step that can contribute to the promotion of an inclusive city is assessing the past and creating 'responsiveness' (UN-habitat [11]). 
As a methodology, a retrospective assessment of process will take place in reference to the dynamics and argumentations, in respect to each particular layer, where the sequential articulation of layers forms the very essence of this 'exceptional territory'.

\section{Historical evolution of city structure/formation of city structure: exceptionality is the evolution of the city walls as a multi cultural artefact}

The overall spatial structure of Nicosia can be defined into two parts. The Historical Walled City, the nuclei of the city, a fortified old town located at the very centre has evolved throughout history upon utility; defence-based developments. The other part is improving Nicosia, developed outside the City Walls since the British Period. The historic core-Walled City will be the focus of the assessment, as all the layers of development can be presented together.

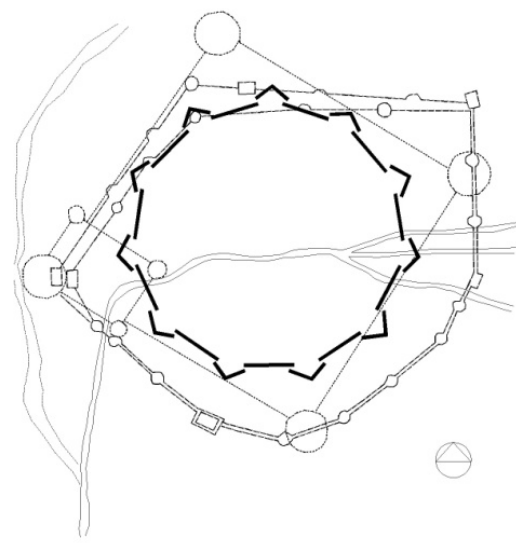

Figure 1: Possible fortification in the Lusignan period and the Venetian Walls and the Pedios River (Diaz-Berio [12]).

The very first spatial definition of historic Nicosia is appeared with the erection of City Walls during the Lusignan period (Atun [13]). The west to east axis of the town was River Pedios which later together with the city walls, the street pattern shaped accordingly (Papadakis [14]). The walls have appeared due to defence reasons, providing safety and exceptionality to the insiders. During the consequent Venetian Period, Lusignian's City Walls were replaced in order to create a more compact and defensive city, where two-thirds of the city was demolished and a circuited wall was developed (figure 1). The street pattern existing today was developed within the confines of the Venetian circuit wall, taking consideration, the location of monumental buildings, palaces and churches (Salvator [15]). 
The labyrinthine streets typical of an Ottoman city encroached upon earlier Lusignan or Venetian foundations, where, three commercial axes developed from the city centre to the gates, to nine of the eleven bastions of the Walls. 'Within this framework, streets developed haphazardly in a maze of narrow winding streets that provided protection from the hot sun' (Salvador [15]).

The traditional fabric of the settlements during the Ottoman Period (15711878), was dependent on a neighbourhood network, which was densely defined with the residential units featuring Ottoman and local attributes, in an organic manner (Salvator [15]). 'Although the traditional housing pattern was determinant in both urban and rural living environments, as the economy was rural based and the housing developments also took dominance in the rural areas' (Atun and Pulhan [16]). It is known that the first form of social division existed due to the population groups with different religion living in different parts of the town. The palace of the Ottoman governor (the Saray) was located on north of the old riverbed, while on the south side of the riverbed lay the administrative centre of the Orthodox Christian population, gathered around the palace of the archbishop who was regarded by Ottomans as the leader of the Orthodox population (Attalides [17]; Haşmet [18]; Hikmetağalar [19]). Houses of Muslim administrators and military officials were located north of the river while those of Christians were to be found south of the river (Atun [13]). Turks had preferred to live in parts near the Famagusta Gate, near the mosque of Tahtakale, and especially in the area of Paphos Gate. The Greeks had chosen principally the district between the Episcopal residence and the Ayia Sophia (Attalides [17]). 'With the process of industrialization, during the British Colonial Period, and after World War II, significant economic changes took place, which facilitated the transition from an agricultural economy to a commercial one (Atun and Pulhan [16]). Although, some administrative buildings were also kept in the traditional walls, rapid urbanization took place, as some wealthier inhabitants started to build big houses with gardens out of the walled city that became the beginning date of the move outside the walls, which the demographic structure that has already changed from the beginning of the $19^{\text {th }}$ century. At that period, half of the inhabitants of Nicosia were Muslim and the Orthodox community made up $49 \%$ of the total dwelling place but they were also distributed amongst Turkish population and the Armenians were mixed up everywhere among the Turks (Attalides [17]). In 1925, when the island was proclaimed a crown colony with Nicosia as its capital, the town is defined by four regions according to the profile of inhabitants as; the Konak District (the most inhabited part, an administrative centre), Cami District (the area used by religious man), Levantine District (mixed residential - all minority groups were concentrated), Cathedral District (Greek religious man) (Attalides [17]; Keshishian [20]).

It is known that, after the Ottoman period, the demographic structure changed significantly, as the Greek Cypriots reached an amount of $70 \%$ of the inhabitants of Nicosia, while the Turkish Cypriots decreased to $23 \%$ of the whole population (Attalides [17]). This was due to the permission given to the Turks by the Ottomans to move to Turkey after they left the Island to the British. During the 
British period, Greeks started to claim more rights than the Turks did since they became a majority and as a result a fight broke out between the two communities (Alpar [21]; Atun and Doratl1 [22]). According to Jeffrey [23], the city, within the walls, was comprised of 25 quarters, distinguishing the following: 14 Muslim, 7 Orthodox, 2 Orthodox and Muslim, 1 Armenian and 1 Latin.

By means of a socio-political way of approach, it is needed to state how the impact of the societal transformations reflected upon the city structure. Parallel to societal changes, such as daily living patterns of people and their locational choices reflected as separations on the physical environment and the spatial structure also started to change.

Spatial effect of separation between different ethnic groups in Nicosia first occurred as 'congregation' in Ottoman period. This is explained as 'voluntary segregation' (Amersfoort and De Clerck [24]) a step after residential mixed which is defined as groups of all kinds living together in a residential area. At that period, there were some residentially mixed places as Muslims and Orthodox lived together, also there were segregated neighbourhoods as they lived in a separate way. Although there were some ethnicity oriented residential areas, there were no ghettos in the meaning of 'no go' areas. So, the choice where to live was based on people's decisions either to live separately or together.

The inner dynamics of the period were the interactions achieved between people with different religious groups reflecting as socio-cultural richness. Outer dynamics was not so apparent until the British colonial period that coincides with the period of Industrialization. The transformation mechanisms were the defence oriented approach of people to the physical setting against a power struggle between different dominations. Interaction between societal and spatial configuration appeared through the voluntary separation of groups and their selective concentration in specific areas reflecting their religious/ethnic identity and shaped according to their daily living patterns.

\section{De-formation of city structure: exceptionality is ethnicity-oriented development and definition}

The setting of traditional city does not have any validity with the changing dynamics of industrialization during the British colonial period. This is the period where the first form of division appeared together in a societal and physical manner. The change of definition in the spatial framework of Nicosia was created after the 1958 partition, as the multi-cultural setting was somehow damaged, by appearing as the ethnicity-based development and the physical setting re-defined accordingly.

With the date of 1958, the 'Mason Dixon' line was established by the British Colonial Administration, in order to separate two groups who could not live together because of diverging national values (Reddaway [25]). This directly reflected the city structure as the northern part as Turkish enclaves and southern part as Greeks. In this way, the city started to segregate into separate enclaves, similar to the definition of a ghetto, described by Johnston [26], as a 'residential 
district that is exclusively the preserve of one ethnic or cultural group'. Whereas, Amersfoort [27], applies another definition, 'a ghetto is an institutionalized residential area in which all the inhabitants belong to a single ethnically or racially or religiously defined group and all the members of this group live in this area'. Here, institutionalized means that the inhabitants who did not choose their dwelling or residential area themselves, they were forced by the rest of the society (Özüekren and Van Kempen [28]). The Cyprus Republic was established in 1960 where the segregation between communities developed a violated form. The period after 1960 could be defined as 'polarized' in many senses, as the two communities became polarized according to their ethnic roots. It is the first time, in the history of the island, where common housing projects were initiated by the Government with the aim of providing low cost, clean and habitable housing units for low-income Turkish Cypriots and Greek Cypriots. Thus, within the Turkish and Greek neighbourhoods several housing schemes were developed in order to fulfil the required housing demand of both communities (Atun and Pulhan [16]). Therefore, the government itself supported the separation between communities by building the housing schemes in Turkish and Greek neighbourhoods without considering a homogenous settlement pattern. Separation gained a new dimension with the increasing tension between the communities accompanying the process of territorial separation and the act of installing separate governmental administrations. This period is important in respect of the fact that these residential segregations gained legitimacy, being supported by government policies at the beginning of the 1960s, with the establishment of the Republic of Cyprus (Atun and Pulhan [16]). It is stated that 'The demands of sub groups are mostly contradictory in polarized communities, and demands cannot be met simultaneously without destroying the existing system' (Rabushka and Shepsle [29]). Therefore, the above statement seems to explain the reason for the division of the city into two, resulting in increasing conflict in 1963. After 1963, the two communities made themselves be segregated in a self-defence way, a way which made themselves feel more secure, and thus the division became more obvious; dividedness literally came on to the agenda. Due to the conflict between the Turkish and Greek Cypriots towards the end of the year 1963, the fragmentation within the physical and social structure of the island necessitated the establishment of separate settlements for the segregated ethnic groups. Because of the inter-communal disputes, a significant percentage of the Turkish Cypriot community had, for the first time, to leave their homes and move to more secure areas or enclaves (United Nations Ortega Report [30]). These enclaves constituted those areas which were controlled and protected areas by the Turkish Cypriots between the years 1963 and 1974, for safety reasons, Turkish Cypriots started to organize themselves politically and socio -economically in this period within specific and unique conditions, under the auspices of the Turkish Communal Chamber, (Atun and Pulhan [16]). Afterwards, almost every function of the city was divided in two, as there was an increasing rate of violence. But, even total segregation of the city into two parts did not prevent the violence and hostility. In 1974, the total division of the city appeared with war, and the last step of segregation 
ended up with a physical division with a rigid boundary, known as the green line, surrounded by a military force. Therefore, instead of cultural and social division, the final step was a military division. It appears to have been two cities instead of one with different administration, different commercial and residential areas. As a result the city became 'deeply divided' as the final step of division. Each stage of division in Nicosia could be expressed within different terms, according to the level of experienced division. The period before 1958 could be called the residential mix, or congregation. People lived together or some preferred to lead separated lives in Turkish or Greek districts and there was no conflict, although it is said that there was a congregation, which was the choice of the people to live separate or together. After 1958, the segregation could be described by means of 'ghettos'. People started to choose to live in separated enclaves because of inter-communal fight. Thus, there was segregation due to ethnicity, religion and politics, and a continuous challenge for power. This period could be called 'contested city' or 'polarized city'. After 1963, the city segregated into ghettos completely; here the segregation was the personal choices: there was a social force reinforcing the segregation as all other social institutions segregated such as schools, public buildings and community organizations.

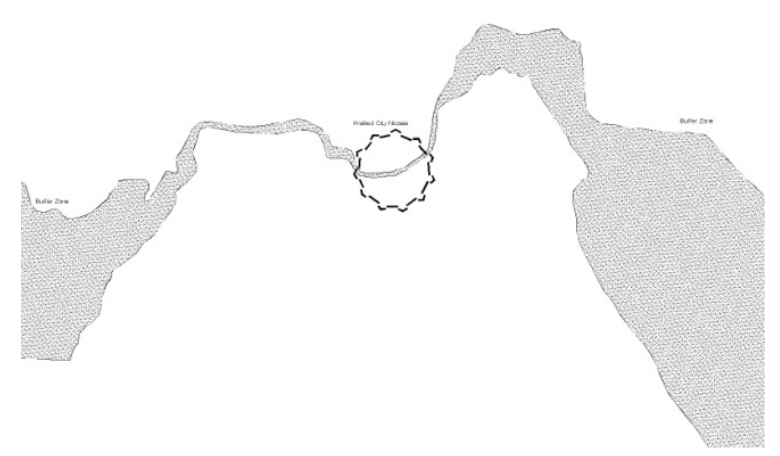

Figure 2: $\quad$ Buffer zone dividing the city (Atun [13]).

The city could be defined as a 'divided city', and in the year 1974 it could be defined as 'deeply divided', where physical, social, cultural, administrative and also political division took place (figure 2). Here, segregation occurred with the military force together with a political force. After that date, the internationally recognized 'Southern Nicosia' the capital of Cyprus, was treated as the 'formal setting' and the unrecognized Northern Part was treated as the 'informal' in the international arena. However, it is not easy to distinguish between formal and informal as two opposing ends. Many people living in a so-called 'informal' manner almost coincided with the ones living in a 'formal' form of living patterns and the connections between formal and informal activity becomes multiple and complex (Perlman [31]). Co-existing in the same landscape, the mutual interaction inevitably creates a 'de-facto' balance in between. The period 
after 2003 is the new span where the challenge of 'keeping the balance' between parts appeared in the form of a 'layer of restructuring'.

\section{Re-formation of the city: exceptionality is redefined setting where urban integration is a goal}

The impact of division and the reality of political uncertainties have had unfortunate effects on socio-economic and physical developments since the middle of the $19^{\text {th }}$ century. Both Northern Nicosia as being an internationally unrecognized 'informal part' and Southern Nicosia as the so-called 'formal' capital of Cyprus are affected from the ongoing status of division. From 1974, Cyprus has had two economies, two governments, two communities and, until 2003, there was no trade or movement of people across the Green Line. The impact of division has been deeply apparent in Nicosia, as the spatial, societal and demographic deterioration occurred rapidly due to unplanned and unsustainable urban transformation (Alpar [21]; Numan and Önal [32]). The city, with two separate municipalities, each responsible for its own infrastructure, commercial, administrative and residential areas of jurisdiction and transportation system has developed in isolation from each other (Louika [33]). Since then, the only cooperation between these separate parts has appeared as the bi-communal Nicosia Master Plan (NMP) brought into agenda by the Mayors of both parts as a response to common infrastructural problems (Petridou [34]).

This attempt has initiated a step towards formulating the NMP as a joint bicommunal planning effort, extending its aim to recover the impacts of division and improve the historic core into a better setting under the UNDP guidance. The emphasis of the NMP were on the revitalization of several pilot areas located on the southern and northern parts of the Walled City of Nicosia as these pilot areas are located very close to the buffer zone. Therefore, the revitalization of the city core began as a bi-communal project in 1987, financed by the UNDP/USAID and implemented on both sides of Nicosia by respective communal authorities. Through these interventions, it is expected to restore the urban fabric, to enrich the historic environment, to attract new residents and economic activity and to stimulate the private initiative to invest in the old city (Loukia [33]). Also, apart from improving the living environment of Nicosia, it is planned to preserve the potential of the historic centre to have a role in the future functional integration of the city (Petridou [34]; NMP [35]). Therefore, two alternative developments are planned; one is without any urban integration between parts and with the other alternative, the condition of urban integration is provided.

Despite urban decay and decline in the city core, its potential for growth and development has been recognized (Atun [13]; Alpar [21]). However, the gradual process of decline set in the once-thriving Walled City core took place as a result of trade contraction, physical decline and demographic transfer to suburbs and alternative population centres (Yorucu et al. [36]). The impact of the Nicosia Master Plan project implementations did not fulfil the constructive provisions of a master plan instead creating project-based physical improvements without any socio-economical developments. 
However, Cyprus and, respectively, Nicosia, are at the beginning of a new span, by the year 2003, after free movement started between two sectors (Northern, Southern Nicosia), the Green Line started to be permeable and 2 checkpoints (Ledra and Metehan) became new urban penetrations outside the Walled City. The role of historic core again shifted into another extent as of 1 May 2004, Nicosia became the capital of one of the newly acceded countries of the EU (Yorucu et al. [36]). This new position provides another definition of Nicosia as a divided city that the border runs through at the middle, produces the EU boundary.

This optimistic and favourable political climate has significantly been supported by the opening of the Lokmac1 Gate, which was the barricade, blocking the movement between traditional Commercial Street, Ledra. Microlevel trade liberalization and people-to-people (civil society) exchange projects operating as a bottom-up dynamic bridging the two communities across the Nicosia divide. This opening was the direct result of the general elections in Southern Cyprus, which replaced the ultra-nationalist Papadopoulos with a more pro-settlement Christofias regime. Settlement talks between $\mathrm{Mr}$ Eroglu and Mr Christofias have been going on ever since, aiming at a possible solution to the Cyprus conflict (Yorucu et al. [36]). This case of trade liberalization has revitalized the main shopping avenue of Ledra Street in the Greek sector of the Walled City and the Lokmaci/Arasta commercial district in the Turkish part extending all the way to Kyrenia Avenue in the heart of old Nicosia (Atun and Doratl1 [22]; Yorucu et al. [36]).

Dialectically, with the new conjunction, the urban structure has the potential for bringing the two parts together to explore new forms of co-operation and coordination as well as to promote economic growth and sustainable development. Here, the 'regeneration' can be a tool as a triggering target for bringing societal and physical concerns together, as a form of public policy shared by two communities.

\section{Conclusion}

Nicosia has evolved through various historical periods, and maintained its exceptionality inadvertently as the outcome of a city's challenge for survival towards 'change'. As change is always a part of the city, in the concern of the article, it has been tried to define the framework: how (dynamics of change), when (periods of change) and what it has changed into (the resultant appearance, subjected to change) to be considered for managing the further stage of development. Therefore, the latest stage: re-formation, engaging the desire of heterogeneity in a social setting and integrated inclusive structure in a spatial social continuum (desired setting to change into) remains a widespread objective, focusing on restructuring the city where the target of 'sustainable development' is placed at the centre. Since the evolution of the city, several modes of 'change' have taken place in societal configuration that later have transformed the urban setting. However, the main essence in the overall configuration of the city is the 'accumulation of distinct layers'; a network with 
strong historical bonds that has a tendency for urban integration and has potential to support future societal interactions as well.

Thus, it can be argued that recent changing political dynamics will act as a mechanism that will foster future spatial integration by re-forming the existing setting into an 'integrated structure'. The bridge between the past and future should be obtained with the supportive tools and mechanisms. Therefore, the target of achieving sustainable development through regeneration is more realistic than ever, provided that effective tools of implementation are used.

\section{References}

[1] Low, S., Theorizing the City, the New Urban Anthropology Reader, Rutgers University Press New Brunswick, New Jersey and London, 1999.

[2] Bourdieu, P., Outline of a Theory of Practice. Cambridge University Press, Cambridge, 1977.

[3] Low, S. M., The Anthropology of Cities: Imagining and Theorizing the City Annual Review of Anthropology. 25, pp. 383-409, 1996.

[4] Merrifield, A., The struggle over place: redeveloping American in Southeast Baltimore, Transactions of the Institute of British Geographers, New Series, 18(1), pp. 102-121, 1993.

[5] Merrifield, A., Place and Space: A Lefebvrian Reconciliation, Transactions of the Institute of British Geographers, New Series, 18(4), pp. 516-531, 1993.

[6] Lefebvre, H., The Production of Space, Cambridge, MA, Blackwell, 1991.

[7] Ollman, B. Dialectical Investigations, Routledge, London, 1993.

[8] Murray, M., Theorizing Cities under Stress, Sage Publications, 2005.

[9] Harvey, D. (1993a) The Nature of the Environment: The Dialectics of Social and Environmental Change, The Socialist. Register, Merlin Press, London, pp. 1-50, 1993.

[10] Kocabaş, A. and Gibson, M. Planned gentrification in Istanbul: the Sulukule Renewal Area 2005-2010, the International Journal of Sustainable Development Planning, vol. 6, no. 4, ISSN: 1743-7601 (print), WIT press, UK, 2011.

[11] UN habitat, State of the World's Cities; Bridging The Urban Divide. United Nations Human Settlements Programme, Earthscan, London, Sterling, VA., p. 118, 2008.

[12] Diaz-Berio, S., Urban Conservation. Nicosia Master Plan, (Unpublished Report), UNDP, UNCHS, Nicosia, 1982.

[13] Atun, R. A., Divided Cities: Physical and Social Restructuring of Nicosia, Cyprus, Unpublished Master Dissertation, METU, Ankara, Turkey, 2001.

[14] Papadakis, Y., Nicosia after 1960: A river, a bridge and a dead zone, Global Media Journal, Mediterranean Edition, 1(1), pp. 1-16. 2006.

[15] Salvator, A. L., levkosia, Triagraph,1983.

[16] Atun, R. A. \& Pulhan, H., Learning From Housing: A Retrospective Narrative of Housing Environments in North Cyprus. Open House International, 2009. 
[17] Attalides, M., Social Change and Urbanization in Cyprus: A Study of Nicosia, Nicosia, Publications of the Social Research Centre, 1981.

[18] Haşmet M. G., A Glance at History Nicosia, Nicosia 1987.

[19] Hikmetağalar, H., Eski Lefkoşa'da Semtler ve Anılar. Marifet Yayınları, 1996.

[20] Keshishian, K., Nicosia, Capital of Cyprus Then and Now. Nicosia, 1990.

[21] Alpar, R., Sustainable Urban Regeneration through the Process of Reunification: Developing a Model for Nicosia. Unpublished Ph.D. Dissertation, Mimar Sinan University (MSU), İstanbul, 2004.

[22] Atun, A. R. \& Doratll, N., Walls in cities: A conceptual approach to the walls of Nicosia, Geopolitics, 14(1), pp. 108-134, 2009.

[23] Jeffrey, G., A description of Historic Monuments of Cyprus, London Zeno, 1918.

[24] Amersfoort, H Van \& De Clerck, L., (eds). The Dynamics of Immigrant Settlement: Surinamese, Turks, and Moroccans in Amsterdam 1973-1983, in G. Glebe and J. O’ Loughlin (Eds) Foreign Minorities.

[25] Reddaway, J., Burdened with Cyprus: The British Connection. London: George Weidenfeld \& Nicolson. 1986.

[26] Johnston, R. J., Spatial Structures: An Introduction to the Study of Spatial Systems in Human Geography. Methuen and Co. Ltd., London (The Field of Geography Series), pp. 137, 1973.

[27] Amersfoort, H. V., Review of Urban Housing Segregation of Minorities in Western Europe and the United States. Ethnic and Racial Studies, 17, pp. 362-363, 1992.

[28] Özüekren, S. and Van Kempen R., Ethnic Segregation in Cities, Urban Studies. Vol. 35, 1998.

[29] Rabushka, A. and Shepsle, K., Politics in Plural Societies: A Theory of Democratic Instability. The ANNALS of the American Academy of Political and Social Science, vol. 404 no. 1, pp. 257, 1972.

[30] UNFICY, Ortega Report, 1964.

[31] Perlman, J., The Myth of Marginality. Urban Poverty and Politics in Rio de Janeiro, Berkeley and Los Angeles: University of California Press, 1976.

[32] Numan, I \& Onal, S., The Reflection of the Social Changes in the Physical and Functional Form of the Walled City. Urban Conservation and Renewal, 1996.

[33] Loukia, L. H., Europa Nostra, International Conference of Historical Towns, Nicosia: Perspectives For Urban Rehabilitation, http://behindwalls.sk/contributionnicosia/2006.

[34] Petridou, A., Workshop on Sustainable and Healthy Urban Transport and Planning, Nicosia Cyprus, 2003.

[35] UNDP, The Nicosia Master Plan: Investment Schemes, Unpublished Statistical Resources, UN Headquarter, Agios Demetrios, Nicosia. 2010.

[36] Yorucu, V., Özay, M., Atun, A. R. \& Uluçay, P., Cross-Border Trade Liberalization: The Case of Lokmaci/Ledra Gate in Divided Nicosia, Cyprus. European Planning Studies, Vol.11, 2011. 